\title{
THE RELATIONSHIP BETWEEN THE FACEMASK USE AND FACIAL SKIN DISORDER IN HEALTHCARE WORKERS AT HOSPITAL, PALU, CENTRAL SULAWESI, INDONESIA
}

\author{
Hesti Azzahra Tosadapotto'), Aulia Chairani²), Sri Wahyuningsih²) \\ 1)Faculty of Medicine, Universitas Pembangunan Nasional Veteran Jakarta \\ ${ }^{2)}$ Department of Public Health, Faculty of Medicine, Universitas Pembangunan \\ Nasional Veterans, Jakarta
}

\begin{abstract}
Background: Skin disorders are diseases that are often found in the community. Complaints of skin disorders can be felt and observed, such as the presence of efflorescence, itching, and stinging. The presence of Coronavirus Disease 2019 (COVID-19) causes adverse dermatological effects due to the use of masks while individuals wear masks to protect themselves from droplets. The irritant ingredients and the use of masks for a long time are the causes of complaints of skin disorders. The purpose of this study was to determine the factors that influence the use of facemask on complaints of facial skin disorders.
\end{abstract}

Subjects and Method: This study was a cross-sectional study. conducted at a hospital, Palu in August 2021. A sample of 60 healthcare workers was selected for this study. The dependent variable was complaints of facial skin disorder. The independent variables were the type of facemask and the duration of using the facemask. The data were collected by questionnaire. The data were analyzed by logistic regression.

Results: Complaints of facial skin disorder in healthcare workers increased with the use of N95 facemask (OR= 5.48; 95\% CI= 1.52 to $19.78 ; \mathrm{p}=0.009)$ and the duration of using facemasks $\geq 7$ hours ( $\mathrm{OR}=0.24 ; 95 \% \mathrm{CI}=0.06$ to $0.87 ; \mathrm{p}=0.031)$. The results of the study found that the most complaints were itching $(51.7 \%)$ followed by other complaints in a row, namely redness (28.3\%), cracked and cracked lips (16.7\%), scaly and dry (13.3\%), painful (11.7\%), burning and stinging (10\%), thickening (5.0\%), and vesicles (1.7\%). In addition, the location of complaints of skin disorders was found mostly behind the ears (27.8\%) followed by other locations such as the area bridge of the nose (25.0\%), cheeks (22.2\%), around the lips (18.1\%), and chin (6.9\%).

Conclusion: Complaints of facial skin disorder in healthcare increase with the use of N95 facemask and the duration of using facemasks $\geq 7$ hours.

Keywords: facial skin disorders, use of facemask, healthcare workers

\section{Correspondence:}

Hesti Azzahra Tosadapotto. Faculty of Medicine, Universitas Pembangunan Nasional Veterans Jakarta. Jl. RS. Fatmawati, South Jakarta 12450, DKI Jakarta. Email: hestiazzahrat@upnvj.ac.id. Mobile: +62 82187552212. 